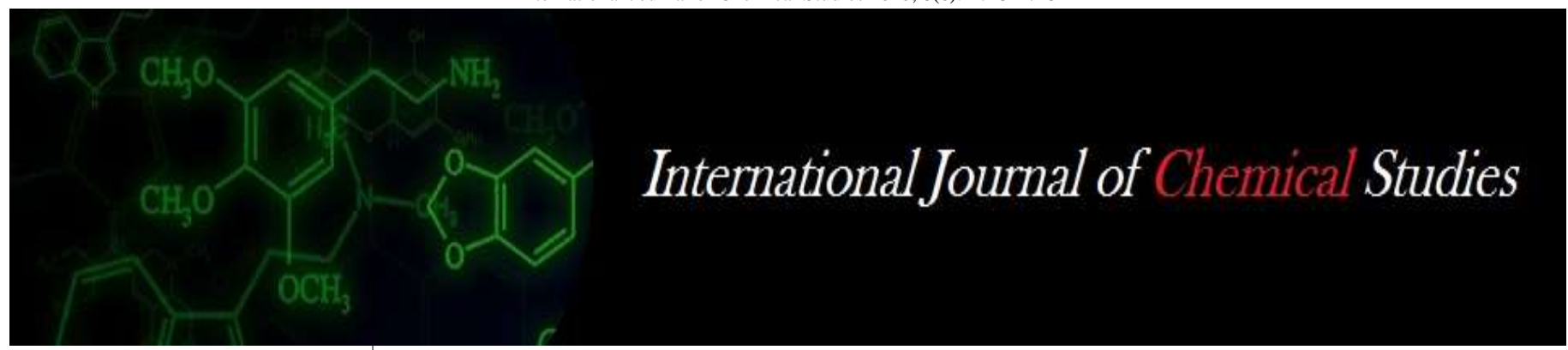

P-ISSN: 2349-8528

E-ISSN: 2321-4902

www.chemijournal.com

IJCS 2020; 8(6): 2743-2745

(C) 2020 IJCS

Received: 15-09-2020

Accepted: 24-10-2020

Sahil Sagwal

M.Sc. Scholar, School of

Agriculture, Lovely Professional

University, Phagwara, Punjab,

India
Corresponding Author:

Sahil Sagwal

M.Sc. Scholar, School of

Agriculture, Lovely Professional

University, Phagwara, Punjab,

India

\title{
Effect of different nitrogen level on the growth and yield of different varieties of hybrid maize
}

Sahil Sagwal

DOI: $\underline{\text { https://doi.org/10.22271/chemi.2020.v8.i6am.11198 }}$

\begin{abstract}
When grown under optimum management practises, maize hybrids yield could be low.The high yield potential of hybrid Maize is unlocked using advanced variants and optimum nitrogen fertiliser application practises. In order to assess the effect of varieties and nitrogen fertiliser rates on yield and yield compounds of maize, an experiment on the farm fields was conducted.in two cropping seasons. It is laid out with randomized complete block design in factorial arrangement with three replications. Five maize varieties (BH-540, BH-543, BH-661, BH-660, and BH-140) as main factor and two levels of nitrogen (55 and $110 \mathrm{Kg} \mathrm{N}$ ha-1) as sub factor were used with one maize variety (BH-543) without fertilizer as control. The application of nitrogen fertiliser rates affected considerably the area of the leaf and maize varieties leaf surface index. All maize yield and yield components were significantly impacted with the interaction of maize varieties with nitrogen fertiliser rates. Using half and full nitrogen fertilisers, the average grain yield benefits over management were 31 percent and 41 percent. Therefore, application of half and full recommended nitrogen fertilizer for improved maize varieties has significantly improved grain yield and recommended for Hybrid maize production.
\end{abstract}

Keywords: Maize, irrigation, fertilisation of nitrogen, harvest index, yield of grain

\section{Introduction}

The world's largest cereal is known as (Zea mays L.). Among the cereal grain crops, maize ranks third in production in world being surpassed only by wheat and rice. Maize, because of its wider adaptability is grown under temperate to tropical regions of world. It is grown in all the countries of the world and occupies 132.26 million hectares with annual production of about 326.41 million tonnes and average productivity of $3980 \mathrm{~kg} / \mathrm{ha}$. U.S.A. has maximum area $(25 \%)$ of total area under maize in world Anonymously in 2001.In India, maize occupies 6th position in production (12.07 million tonnes), 5th position in area covering 6.87 million ha and 3 rd position in productivity producing $1800 \mathrm{~kg}$ per ha (AICMIP) in 2000.Though it is consumed all over the country but it is a staple food of people in hilly and sub mountain areas of North India. It is extensively grown in Uttar Pradesh, Bihar, Andhra Pradesh, Karnataka, Rajasthan, Madhya Pradesh, Punjab and entire hilly areas of Himalaya as a fodder and grain crop. These states account for more than 79 percent of area and 81 percent of the production of maize. The maize is cultivated mainly for food, fodder, food and industrial uses. It is staple food for tribul and poors in the country. More than 3500 products of daily application and derived from maize. It is the crop of future as mentioned by father of green revolution Renowed Nobel Laureate Dr. Norman E. Borloug. Maize can play vital role in ensuring food security as well as nutritional security by use of quality protein maize for the country as well as for world as whole. Maize is largely consumed as food in various forms. About $85 \%$ of maize produced in the country is consumed by human in the form of chappati, rawa, maida and other products. Green shells are roasted and consumed by interested people. Green maize plants are used as succulent fodder. Maize is a method of cooking starch. It is also good food for piggery, poultry and other animals. Maize is a raw material for number of products eg high fructose syrup, maltodextrin, germ oil; sprouting applications in industries such as tobacco, textiles, paper, pharmaceuticals; organic chemical, cosmetics and edible oil starch, lactic acid, glucoses, acetic acid, dextrosis, sorbitol, dextrin etc. Maize based industry is the driving force for the U.S. economy. Maize contains about 10 percent albumin, 2.3\% crude fibber and $1.4 \%$ ash.Maize grain contains vitamin A. riboflavin and vitamin $\mathrm{E}$. 
Maize is traditionally grown as rainy season crop in India. It is cultivated as winter crop recentlypast in certain part of country. The process of bringing new land under this crop cannot continue much longer in a developing country like India. Further increase in production of maize must come largely from higher yields per unit time which will require the transfer of better technology, particularly of fertilizer applications at farmer's level. The major constrains in boosting the yield of maize are lack of improved package of practices viz. Optimum use of fertilizer sowing time and improved varieties etc. Among these one of the factor responsible for limiting the yield of maize is inadequate use of major nutrients. Earlier research workers showed that an application of nutrient particularly nitrogen, phosphorus and potassium seems to be beneficial for increase the growth and yield of maize. With the introduction of new hybrids it becomes essential to find out the knowledge of application of fertilizers, their doses, method and rate of application should be properly evaluated for maize.

\section{Review of literature}

\section{Effect of Nitrogen Fertilization of various Growth Attributes of Hybrid Maize}

The effect of different levels of nitrogen was observed both at 50 DAS and at harvest (90 DAS) and the maximum height (69.93 and 254.89 respectively) was recorded in M4 (i.e 150 $\mathrm{kg} \mathrm{N}$ ha-1) which in both cases was considerably higher than all other concentrations of nitrogen. Similarly, in summer. At 50 DAS, there was a significant effect of time when nitrogen was applied to the plant height and the highest value in S1 (67.60), followed by S3, was observed and the lowest in S2 (59.50). The probable reason behind the result might be that the $\mathrm{S} 1$ plots received full dose of $\mathrm{N}$ by 25 DAS whereas S3 plots received $75 \%$ and $\mathrm{S} 2$ received only $50 \%$ of full $\mathrm{N}$ levels within this period which helped faster growth of the plants. At harvest, time application of nitrogen on plant height was also found statistically significant and the higher plant height of $252.16 \mathrm{~cm}$ was recorded in S3 followed by $\mathrm{S} 1$ and $\mathrm{S} 2$. In plant heights at different growth stages such as 25 DAS, 50 DAS and in harvest, the interaction effect of hybrid maize at various levels and time of the nitrogen programme has not been found to be significant. Amanullah et al. (2007) [3] reported that plant height of maize was significantly increased with the application of $180 \mathrm{~kg} \mathrm{~N}$ ha-1 as compared to 60 and $120 \mathrm{~kg} \mathrm{~N}$ ha-1 at Peshawar (Pakistan). Muniswamy et al. (2007) [20] has also recorded a rise in plant height with increasing nitrogen levels, but its inefficient use is harmful for environment degradation of water quality and increasing NO3-N accumulation in soil. Qiu et al. (2014) ${ }^{[21]}$ reported that Application of $\mathrm{K}$ significantly increased the average maize yields by 15.1 and $13.8 \%$ in the 113 and $225 \mathrm{~kg}$ ha-1 K2O treatments, respectively. Mean $\mathrm{K}$ recovery efficiency decreased from $37.3 \%$ to $28.5 \%$ when the $\mathrm{K}$ doses increased from 113 to $225 \mathrm{kgha}-1 \mathrm{~K} 20$.

\section{Effect of Nitrogen on yield and yield attributes}

The effect of different levels of nitrogen with its different time of application did not significantly influence the number of cobs per plant. Brajmani et al. (2010) ${ }^{[22]}$ reported that, the nitrogen levels did not showed any significant effect on number of cobs plant-1 of maize at Allahabad, U.P. Kaur et al. (2018) [10] reported the similar trend in hybrid maize.Interaction effect of different levels and time of application of nitrogen on grain yield of maize was found statistically significant and the better effect. Jat et al. (2013)
[7] identified that nitrogen $(\mathrm{N})$ is very important because this element is responsible on major activities for growth and development of maize crop.

\section{Effect of Nitrogen on Benefit cost Ratio}

Effect of different nitrogen levels and their time of application on benefit cost ratio of hybrid maize was observed and it was found that different nitrogen levels significantly influenced. The benefit cost ratio but the effect was not significant in case of time of application of nitrogen. Onasanya et al. (2009) [11] had suggested that the response of maize plant to application of $\mathrm{N}$ fertilizers varies from variety to variety, location to location and also depends on the availability of the nutrients. Nxumalo et al. (1993) ${ }^{[19]}$ indicated that the increase in maize grain yield after nitrogen fertilization is largely due to an increase in the number of ears per plant, increase in total the dry matter is dispersed to the grain and raises the weight of the ear. Shrestha et al. (2018) ${ }^{[15]}$ exprimented that Nitrogen response by maize differs due to growth stages, environment and genotype of maize. Hybrid and improved maize varieties are more nitrogen-responsive than local varieties of maize. Amoruwa et al. (1987) ${ }^{\text {[17] }}$ reported that thousand grains weight increased with increasing nitro-gen rate. Different yield attributing parameters like grain yield ( $\mathrm{t} / \mathrm{ha}$ ), numbers of cobs/ha and thousand grain weights $(\mathrm{g})$ were calculated for each varieties in spring season of 2018 spring. Khan et al. $(2014)^{[8]}$ reported that numbers of cobs/plant of maize increased with increased in nitrogen rates as compared to control and other treatments. Andrea et al. (2006) [18] identified that the application of nitrogen at low rates reduced grain yield of maize by $43-74 \%$ and number of grains per plant up to $33-65 \%$. The increased nitrogen dose increases maize seed production and protein concentrations. Kaur (2019) ${ }^{[10]}$ reported similar patterns in hybrid maize.

\section{Conclusion}

Maize varied organics and crop yields have been dramatically different. Indicably higher average maize yield was obtained by adding nitrogen fertiliser. Increased shoot and grain $\mathrm{N}$ accumulation of maize varieties is used for nitrogen fertiliser. Higher maize variety nitrogen harvesting index were accomplished with half of a recommended nitrogen fertiliser relative to maize planting with maximum recommended application of nitrogen fertilisers. Nitrogen fertilizer was agronomically given higher grain yield and economic feasibility. For the sustainable maize production, the planting of maize species with the best application of nitrogen was thus far more significant.

\section{References}

1. Parihar CM, Jat SL, Singh AK, Kumar RS, Hooda KS, GK C et al. Maize production technologies in India2011.

2. Maize NU, EOH. Influence of varying nitrogen levels on growth, yield and. Journal of Experimental Biology 2017;5:2.

3. Amanullah, Shah P. Nitrogen rates and its time of application influence dry matter partitioning and grain yield in maize planted at low and high densities. Journal of plant nutrition 2010;34(2):224-242.

4. Sp P. Response of sweet corn hybrid to varying plant densities and nitrogen levels. African Journal of Agricultural Research 2012;7(46):6158-6166.

5. Pepó P, Karancsi GL. Effect of fertilization on the NPK uptake of different maize (Zea mays L.) genotypes. Cereal Research Communications 2017;45(4):699-710. 
6. Sharma R, Adhikari P, Shrestha J, Acharya BP. Response of maize (Zea mays L.) hybrids to different levels of nitrogen. Archives of Agriculture and Environmental Science 2019;4(3):295-299.

7. Ansari MA, Roy SS, Sharma SK, Jat SL, Singh IM, Prakash $\mathrm{N}$ et al. Souvenir of national workshop cum brainstorming session on "Unleashing the hidden potential of maize technology in $\mathrm{NEH}$ region: status, options and strategies 2018.

8. Khan F, Khan S, Fahad S, Faisal S, Hussain S, Ali S, Ali A. Effect of different levels of nitrogen and phosphorus on the phenology and yield of maize varieties. American Journal of Plant Sciences, 2014.

9. Asif M, Saleem MF, Anjum SA, Wahid MA, Bilal MF. Effect of nitrogen and zinc sulphate on growth and yield of maize (Zea mays L.). Journal of Agricultural Research (03681157) 2013,51(4).

10. Kaur G, Guo J, Brown S, Head GP, Price PA, Paul oraes S, Huang F. Field-evolved resistance of Helicoverpa zea (Boddie) to transgenic maize expressing pyramided Cry1A. 105/Cry2Ab2 proteins in northeast Louisiana, the United States. Journal of invertebrate pathology 2019;63:11-20.

11. Onasanya RO, Aiyelari OP, Onasanya A, Oikeh S, Nwilene FE, Oyelakin OO. Growth and yield response of maize (Zea mays L.) to different rates of nitrogen and phosphorus fertilizers in southern Nigeria. World Journal of Agricultural Sciences 2009;5(4):400-407.

12. Cui Z, Chen X, Zhang F. Current nitrogen management status and measures to improve the intensive wheatmaize system in China. Ambio 2010;39(5-6):376-384.

13. Sutar RK, Pujar AM, Kumar BA, Hebsur NS. Sulphur nutrition in maize-A critical review. Int. J Pure App. Biosci 2017;5(6):1582-1596.

14. Shariot-Ullah M, Mojid MA, Tabriz SS, Acharjee TK, Adham AKM. Growth and yield of three hybrid maize varieties under different irrigation levels. Journal of Agricultural Technology 2013;9(7):1749-1758.

15. Adhikari P, Baral BR, Shrestha J. Maize response to time of nitrogen application and planting seasons. Journal of Maize Research and Development 2016;2(1):83-93.

16. Jogdand PB, Kadam GL, Talnikar AS, Karande DR. Response of maize (Zea mays L.) hybrids to fertility levels in kharif season. Intern. J Agric. Sci

17. Amoruwa GM, Ogunlela VB, Ologunde OO. Agronomic performance and nutrient concentration of Maize (Zea mays L.) as influenced by nitrogen fertilization and plant density. Journal of Agronomy and Crop Science 1987;159(4):226-231. 2008;4(1):225-230.

18. D'Andrea KE, Otegui ME, Cirilo AG, Eyherabide G. Genotypic variability in morphological and physiological traits among maize inbred lines-nitrogen responses. Crop science 2006;46(3):1266-1276.

19. Nxumalo EM, Pali-Shikhulu J, Dlamini S. Assessment of nitrogen fertilizer use efficiency in commercial maize hybrids. In Proceedings of the Annual Scientific Conference of the SADCC-Land and Water Management Research Programme 1993,322-329.

20. Muniswamy S, Gowda R, Rajendra Prasad S. Effect of spacing and nitrogen levels on seed yield and quality of maize single cross hybrid PEHM-2. Mysore Journal Agricultural Sciences 2007;41(2):186-190.

21. Xu X, He P, Pampolino MF, Johnston AM, Qiu S, Zhao S. Fertilizer recommendation for maize in China based on yield response and agronomic efficiency. Field Crops Research 2014;157:27-34.

22. Brajmani G, Rajesh S, Lal GM. Effect of levels of nitrogen and sulphur on growth and yield of maize (Zea mays L.). Journal of Maharashtra Agricultural Universities 2010;35(1):149-151. 